\title{
Article
}

\section{The 'goss' on Paul and Heather: Attitudes to celebrity and divorce in three NZ women's magazines}

\section{A.BSTIRACII}

In recent years, the range of mass media available in New Zealand and the Pacific generally has come under increasing attention from scholars, notably in this journal. However, New Zealand women's magazines, although widely read, have not received the same depth of scholarly attention. On the social constructionist principle that close analysis of written texts can suggest much about the society in which they are embedded and the social functions they perform, this article examines 34 items about the separation of Paul McCartney and Heather Mills from the New Zealand Women's Weekly, Woman's Day, and New Idea from 3 June to 30 December 2006, to investigate the nature of gossip's appeal in general, and the magazines' attitudes to divorce in particular.

Keywords: celebrity, divorce, privacy, tabloid journalism, women's magazines

ROSEMARY BREWER

AUT University

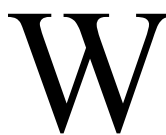

ITH the New Zealand Women's Weekly, Woman's Day and New Idea collectively selling over a quarter of a million copies in the second six months of 2008, New Zealand women's magazines continue to be very widely read (ABC Knowledge Base, 2009). On the social constructionist principle that close analysis of written texts can suggest to us much about the society in which they are embedded and the social functions 
they perform, I examined 34 items about the separation of Paul McCartney and Heather Mills from the New Zealand Women's Weekly (NZWW), and New Zealand editions of Woman's Day (WD), and New Idea (NI) from 3 June to 30 December 2006, curious about the nature of gossip's appeal in general, and the magazines' attitudes to separation and divorce in particular.

Much has been written about the effects of divorce on families; in a recent example, Hillcoat-Nalletamby, Dharamlingam and Baxendine, 2006, discuss its impact on parent and adult child relationships in New Zealand. Its increased incidence over recent decades is understood (and often deplored) throughout Western-style communities. Attitudes to divorce do vary, however, and judgements are commonly made not only about divorce itself, but also about the way a couple or family negotiate the difficulties it presents them with. Divorce, with its public declaration of interpersonal matters commonly kept private, is also a topic particularly suited to gossip.

Foster (2004) defines gossip as talk about third parties not present which makes moral judgements about their private lives. Baumeister, Zhang and Vohs (2004) see its function as a form of social learning which 'involves codes of conduct and moral rules embedded in concrete stories ... (which serve) ... as a policing device that cultures employ as a low-cost method of regulating members' behaviour' (p. 115). Gossip seems to fulfil a need in us to understand the most affective realm of our lives-by telling us what other people do in their most personal relationships, and gives us the freedom to judge it against what we know of prevailing norms. And gossip in the tabloid-style media means we can learn about the ostensible private lives of famous people, without any penalty to ourselves in terms of being viewed as inquisitive, 'nosy' or malicious. Foster also notes that all gossip relies on privacy and informality; just as workmates will only gossip where they won't be overheard, so readers may indulge in gossip with impunity by reading it in a magazine - in both cases, the subjects of the gossip should never know.

Gossip articles in women's magazines typically recount a series of events which happen to characters within a context, and so can be regarded as as much a narrative as any novel. In his seminal work on logic, including a 1987 essay entitled 'Technical Logic, Rhetorical Logic, and Narrative Rationality', Walter Fisher proposed that a story is a way we can make sense of things, just as logical argument is. He said we test narratives for their rationality, just as we do other types of argument. With a story, we consider two things: 
its probability (internal coherence and the believability of its characters) and its fidelity or truthfulness - what he called the 'logic of good reasons' or the 'ring of truth' of a story.

Central to all stories is character. Whether or not a story is believable depends on the reliability of characters, both as narrators and as actors. Determination of one's character is made by interpretations of a person's decisions and actions that reflect values.... Coherence in life and in literature requires that characters behave characteristically. Without this kind of predictability, there is no trust, no community, no rational order (Fisher, p.16).

So, according to Fisher, in stories we are looking for representations of commonly held values and beliefs, and we test stories for their believability and internal logic. We therefore assess a story's characters (and narrator) on their fundamental values, and decide whether they are in alignment with our own. In this way we reflect on our own value-laden beliefs, and make moral or ethical judgements on the characters we hear about. In addition, Wert and Salovey (2004) suggest that gossip transmits and reinforces individual social identity, our sense of who is 'like us' and who is 'other', and that it upholds group norms in the form of an imagined perfect embodiment of the group. In listening to gossip we are learning how to better conform to the group's norms by contrasting ourselves with the characters being gossiped about.

When stories such as the separation of Paul McCartney and Heather Mills are told in the media, no matter how accurate or misleading the narratives about them may be, readers use them to make judgements and to reflect on their own values and beliefs, as well as those of the communities they see themselves as aligned with. Huisman, in Fulton et al (2005), notes that
... recent magazines have very little overt fiction, but are filled with stories of 'real people'. The 'cult of celebrity' ... gives our society the characters - the 'narrative existents' - through which dominant social myths can be told: stories of individual success, failure, romance, feud, tragedy (although rarely comedy) (p.280).

The narratives of gossip, whether around the village pump, in a staff room, or spread through the tabloid press, have a serious function for us - the confirmation or modification of ways of seeing ourselves and our community, and 
this has the potential to give the purveyor of the story/gossip a kind of social influence. If we, as the audience, are going to have our individual values and beliefs reinforced or modified, it will happen through the way the story is told, and the ways the characters are represented. Huisman goes on to describe how the characters in the tabloid press, whatever their real personalities may be, are discussed in terms of character types that will be familiar to the reader. They are simplified and type cast.

Such use of stock characters means that gossip articles have much in common with melodrama and its modern cousin, the soap opera. According to Lacey (2000), 'melodrama is clearly one of the dominant modes of discourse in Western society' (p. 205). Lacey's list of the characteristics of melodrama, including the simplification of characters into embodiments of good and evil, the celebration of overt emotionalism, clear-cut solutions to conflict, excess and exaggeration (pp. 203-204), can be applied to both soap operas and gossip articles. Gledhill (1987) is less categorical, but agrees that 'the melodramatic mode organizes an imaginative world constructed on the principle of terminal conflict between polarized moral forces that run through the social fabric and are expressed in personal and familial terms ...' (p. 107) and it employs 'highly codified plot structures ... (and) ...character types...' (p. 106). Gledhill concludes that soap opera has much of this in common with melodrama, despite its origins in a realist tradition.

The following reports on my discourse and semiotic analysis of 34 items about the McCartney divorce published in the New Zealand Women's Weekly and New Zealand editions of Woman's Day and New Idea from 3 June to 30 December 2006, a seven month period following the couple's separation in May. It looks first at representations of the key protagonists in terms of archetypes, then at attitudes towards divorce in general, and finally at the positioning of the reader as a covert consumer of gossip narratives about celebrities.

\section{The McCartney divorce}

Paul McCartney, most famous for having been a Beatle, was widowed in April 1998 after a long marriage. He was first seen publicly with Heather Mills, 26 years his junior and well known herself as a worker for charities and a former model, in January 2000. Mills had a leg amputated as a result of a motor bike accident in 1993, which seems to have contributed to her fame. Mills and McCartney married in June 2002 and had a daughter in 
October 2003. On 17 May 2006, photographs were published of a furious Mills unable to enter their family home because McCartney had changed the locks. He filed for divorce a month later. They had not signed a prenuptial agreement, so Mills was entitled to claim a significant amount of money as part of the divorce settlement, McCartney being one of the wealthiest men in Britain, and its richest musician (BBC News, 6 March 2004).

So this is the story. The main characters are Mills and McCartney, but a host of minor characters inhabit the articles, most frequently McCartney's adult daughter Stella, famous in her own right as a fashion designer, and the couple's young daughter, Beatrice. Family rows, private conversations and one person's opinion of another are reported as if true, and mostly attributed to 'insiders' or 'a friend', or a person 'close to the couple'. Few sources are named, although they are reputedly paid for the information, and the authors sometimes avoid the problem of verification altogether in such passive constructions as ' ... now Heather Mills is being branded a gold-digger' ( $N Z W W$, 14 August 2006, p. 14) and 'it was revealed' (WD, 19 June 2006, p. 109). But then gossip is not required to have a rigorously proven provenance in ordinary life either.

The collection of 'friends' and 'insiders' have a role to play as the wise conscience or common sense voice, warning, commenting on, justifying or deploring the behaviour of the main characters, reminiscent of the chorus in Greek tragedy. For example, from the $N Z W W$ July 3 article ${ }^{e} \ldots$ when people warned him that they would not be compatible as a couple, he refused to listen' (p. 16), and later in the same article a media commentator is quoted as saying 'Heather will get all the money she could possibly need, but she hasn't got the one thing she really craves - to be loved by the public'. In the November 4 article in New Idea, friends of McCartney said they had warned him Mills was a liar, but he had not listened. Of interest is the use of the word 'camp' to describe these partisan sources of information about the couple. It is most frequently used to refer to the friends and supporters of Mills and suggests a negative attitude towards them by the publication.

Unlike either Woman's Day or New Idea, the New Zealand Women's Weekly articles have named authors, and there is some variation between these in style. However, most of the information in all three magazines, like any good gossip, may be considered to have multiple authors: the sources, the interviewing journalist, the original publication and its editors, and then 
further editing when it reaches New Zealand. The authenticity of the claims, therefore, cannot be proved, and is not the subject of this study. The way the story is told and the attitudes it reveals are.

\section{Representations of Heather Mills and Paul McCartney, 3 June- 30 December 2006}

Weimann (2000) discusses how media producers actively select words and images, and how audiences actively select which of them they will pay attention to. The magazines' selection of this couple is, of course, because they are celebrities and known to readers from previous texts about their courtship, marriage and the birth of their daughter. Widespread publicity about the couple allows the authors to use the language of informal gossip, where first names alone are employed, and the readers' knowledge of prior events (such as the birth of their child) is assumed. Just as 'Cinderella' or 'Marilyn' as unmodified labels are instantly recognisable to this audience, so 'Paul' and 'Heather' are written about not only as participants in particular events, but also as characters in an on-going narrative. Huisman (in Fulton et al, 2005) comments of other tabloid pieces: 'Like the orally transmitted stories of traditional Germanic culture ... or the televisually transmitted stories of contemporary soap operas, the magazine story traverses a shared field ... in which characters are already established and recognised.' (p. 281).

In all three magazines, representations of Paul McCartney focus on his age, his status as an ex-Beatle and his wealth (see Table 1 ). Woman's Day refers to his age most often in nine out of 14 articles, seven of them alongside Mills' age. Implicit in this may be a disapproving attitude towards marriages with a large age gap, particularly as articles about other couples rarely mention their ages, except in relation to the woman's fertility. Disapproval of May-December marriages is made explicit in repeated references to the opposition of McCartney's family (for example in $W D$, June 5 and August 28, NI November 4, NZWW July 3, August 14 and 28). Although two mentions are made in the New Zealand Women's Weekly of McCartney's musical talent, they are in the context of whether or not he could claim it as a factor in the financial settlement of the divorce (August 28) and in his own report that he composed songs as therapy when upset over 'family matters' (December 18). His wealth is, of course, at the bottom of all the speculation about the divorce settlement. 
The articles in all three magazines keep a firm focus on private relationships between the main characters and attributions made about their motives. Of McCartney's motives for marriage, the $N Z W W 3$ July article asserts 'the entire disaster was caused by the oldest human urge in the world - sex' (p. 16) and they characterise him as a lonely widower swept away by the beauty of a manipulative and much younger woman. From the same article, and attributed to 'friends': 'They went on a number of platonic dates until he became hugely in thrall to her. She told him it wasn't appropriate for them to start a physical relationship because he was still in mourning for Linda. He was devastated and began to pursue her relentlessly. The simple fact is he became sexually besotted with her' (p. 16).

The depiction of McCartney as a wealthy widower (rather than a musician) recalls the widowed fathers in the Grimm's fairy tales 'Hansel and Gretel' and 'Snow White'. They both marry evil younger women and are so in love that they fail to protect their children. In both stories the children love and forgive the father, but suffer at the hands of the evil woman he has married. In both stories the stepmother dies at the end-horribly, in the case of Snow White's - and the children are left to continue happily with the father. His failure to protect them from the stepmother is not an issue and it's very firmly a 'happy ending'. The story of Paul and Heather has marked similarities to these classic tales and the reduction of McCartney to the stock type of the lonely, but wealthy widower, easy prey for the greedy young beauty, is clear, particularly in the July 3 article cited above, but also in the first Woman's Day article (June 5), which includes an unattributed quotation that he was "blinded by sex' (p. 14).

Not only can this story be seen in terms of folk tales, in the $N Z W W$ November 6 article it is also characterised explicitly as a melodramatic soap opera. Headlined 'the drama continues' it begins: 'If their marriage was a fairy tale, the break-up of Sir Paul McCartney ... reads like the plot of one of the more far-fetched soaps'. The body of the article divides the material into 'episodes'. However, all 34 articles have some of Lacey's (2000) characteristics of melodrama (see above). For example, Stella McCartney's purported hatred of Mills ( $N Z W W$ November 13; NI November 11) is a 'celebration of overt emotionalism' (p. 204). The $N Z W W$ article begins 'Paul McCartney's daughter Stella flew into a rage and threatened to kill her stepmother Heather Mills, in a blazing bust-up during which the temperamental fashion designer 
had to be restrained'. The author of the $N Z W W$ November 6 article concludes with the rather sanctimonious comment, ' $\ldots$ and Bea's third birthday party is cancelled', giving it a suitably melodramatic ending.

The fairy tale and soap opera comparisons are also borne out in the representations of Heather Mills, which are much less forgiving than those of McCartney, particularly as time goes on. While one of the headlines of the first $N Z W W$ article on July 3 is 'Heather's heartbreak' and the other quotes a Beatles song 'Can't buy me love'; the headline of the final article of the series on December 18 is much more damning of her character, calling her 'A hard, dazed wife'. In the latter article, the authors accept her assertion that she has had death threats (for unsavoury internet posts about her, one only need go to fametastic.co.uk, or omg.yahoo.com), but dismiss her fear of them and disclosure that she may have need of her training in martial arts with the commentary: 'If this seems to be taking personal protection a little literally, it's because she has no money for bodyguards, she claims'. They call these 'claims' 'curious', when 'she has twice been spotted viewing a \$2.4 million 18th century farmhouse' (p. 14) and locate them beside a waist high, halfpage photograph of McCartney with his lips pursed, his hands clasped, and a facial expression which could be interpreted as doubting or rueful. In such indirect ways are the readers encouraged to brush off the validity of those fears, all the while being purchasers of the tabloid publications which fuel the gossip, and so potentially the threats themselves. Indeed the front cover of the same edition has a small photo of Mills and her daughter with the caption 'BEATRICE AT RISK! Heather's extreme protection scheme' - with the clear implication that she is overreacting.

The Woman's Day and New Idea articles are, if anything, more damning of Mills than the Weekly. Seven out of the 14 WD articles and five out of the $11 N I$ articles refer to Mills' previous career as a topless model and repeat allegations that she had been a call girl, whereas the closest the $N Z W W$ comes to discussing this is the rather coy descriptor of her as a 'one-time lingerie model' (14 August, p. 14). As an illustration of the magazines' characterisations of Mills and McCartney (Table 1) lists descriptors of our two main protagonists in the order they appeared in the nine items of the NZWW, to demonstrate style and progression. Quotations marks indicate that an informant is being directly quoted in the article.

Although not all references complimentary of McCartney and negative 
about Mills, the overall depiction of Mills is as untrustworthy, attention seeking and greedy. The most extreme and damning expressions are quotes from mostly unnamed sources, although the worst against Mills, in the December 18 article, are attributed to Stella McCartney. In contrast, accusations of bad behaviour against McCartney are either not commented on, or are attributed to an unreliable source (his stepsister, from whom he is estranged, on December 18, and to Mills and her friends). In addition, repeated use of McCartney's title and reputation tend to reinforce his personal credibility.

There is evidence of a distinct bias against Mills, even in the $N Z W W$, and even when she is being discussed with apparent sympathy. In an early $N Z W W$ article (July 17) there is an attitude of approval when Mills is reported to be considering a relatively small settlement. The implication is that she should prove she is not a 'gold-digger' (the most frequently used accusation against her) by settling for less and not making a fuss. The August 14 article is quite even-handed, concluding that, although Mills and McCartney accuse one another of wrong-doing, 'the gloves as well as the wedding rings, are off' as the financial settlement looms (in fact it wasn't finalised until March 2008, nearly two years later). The 28 August article also gives both sides of the story, but McCartney's comes first and takes up the most space (seven paragraphs, with two for Mills' story). The October 9 edition has a paragraph and photograph of Mills in its 'Starnews' column, reporting that she was ejected from a supermarket because she had allegedly stolen from it as a teenager. This is irrelevant to the dominant story line of the article sequence, but supports its predominantly critical attitude towards her.

This vilification of Mills in all three magazines is consistent with the fairy story paradigm. If a much younger and very beautiful woman marries a wealthy and famous man, her motives must be greed and ambition. No alternative explanation seems to be seriously considered by any of the magazines. Although they do print protestations from Mills herself and her friends, arguing that she has made significant contributions in both money and time to the charities she supports, these are frequently undercut by the author's voice, most directly in the NI November 4 article, which has a subheading: 'Inside Heather's fantasy world: Heather's questionable claims and counter-claims about her career, childhood and relationships only discredit her' (p. 17). The WD June 5 article quotes an informant that she is 'inconsolable' about the break-up, then two paragraphs later suggests she is really 'a gold-digging 


\begin{tabular}{|c|c|c|}
\hline NZWW Edition (2006) & Heather Mills & Paul McCartney \\
\hline 3 July pp.16 - 17 & $\begin{array}{l}\text { Charity campaigner Heather Mills } \\
\text { Heather } \\
\text { Gold-digger who only married her much } \\
\text { older husband because she craved } \\
\text { wealth and status } \\
\text { 'She craves attention and she always } \\
\text { wanted to be the new Princess Diana' }\end{array}$ & $\begin{array}{l}\text { Sir Paul McCartney } \\
\text { Paul }\end{array}$ \\
\hline 17 July p.6 & $\begin{array}{l}\text { Heather Mills-McCartney } \\
\text { Ex-model } \\
\text { Heather } \\
\text { 'devastated over the break-up' }\end{array}$ & Sir Paul McCartney \\
\hline 14 August p.14 & $\begin{array}{l}\text { Heather Mills } \\
\text { Gold-digger } \\
\text { One-time lingerie model } \\
\text { 38-year-old Heather }\end{array}$ & $\begin{array}{l}\text { Sir Paul } \\
65 \text {-year-old singer } \\
\text { 'a reasonable guy who } \\
\text { doesn't like confrontation' } \\
\text { the music superstar }\end{array}$ \\
\hline $\begin{array}{l}28 \text { August } \\
\text { pp.12-13 }\end{array}$ & $\begin{array}{l}\text { Heather } \\
\text { 'argumentative' } \\
\text { 'rude to staff' } \\
\text { 'grounded in the real world' } \\
\text { 'a fake' }\end{array}$ & $\begin{array}{l}\text { 'controlling' } \\
\text { the singer } \\
\text { 'not the Mr Nice Guy people } \\
\text { think he is' } \\
\text { 'bad-tempered' } \\
\text { 'rude and standoffish' } \\
\text { 'extraordinary talent' }\end{array}$ \\
\hline $\begin{array}{l}9 \text { October } \\
\text { Star News p. } 4\end{array}$ & $\begin{array}{l}\text { Heather Mills } \\
\text { Estranged wife }\end{array}$ & Paul McCartney \\
\hline 6 November p.14 & $\begin{array}{l}\text { Heather Mills - one-legged landmine } \\
\text { campaigner and former model }\end{array}$ & $\begin{array}{l}\text { Sir Paul McCartney - } \\
\text { billionaire former Beatles } \\
\text { genius and hippy }\end{array}$ \\
\hline $\begin{array}{l}13 \text { November } \\
\text { pp. } 14-15\end{array}$ & $\begin{array}{l}\text { Former model } \\
\text { 'a money-grabbing bitch' }\end{array}$ & $\begin{array}{l}\text { Former Beatle Paul ( } 64) \\
\text { The legendary musician }\end{array}$ \\
\hline $\begin{array}{l}11 \text { December } \\
\text { Star News p. } 4\end{array}$ & Heather Mills & Sir Paul McCartney \\
\hline $\begin{array}{l}18 \text { December pp. } \\
14-15\end{array}$ & $\begin{array}{l}\text { The most hated woman in Britain } \\
\text { Former model } \\
\text { Heather Mills, the much-pilloried wife of } \\
\text { Paul McCartney } \\
\text { 'a manipulative cow' } \\
\text { 'a bloody gold-digging disgrace' } \\
\text { 'one-legged bitch' } \\
\text { 'a bitch from hell' } \\
\text { 'liar' }\end{array}$ & $\begin{array}{l}\text { Sir Paul McCartney } \\
\text { Sir Paul } \\
\text { Paul } \\
\text { 'a man with a huge ego who } \\
\text { has been used to having his } \\
\text { own way for decades' }\end{array}$ \\
\hline
\end{tabular}


seductress', alongside a close-up photograph of her taken from below, looking directly at the the reader with narrowed eyes and pursed lips. According to Kress and Van Leeuwen, 1999, poses like this represent dominance or symbolic power, which in this instance, when read along with the text, may be interpreted as arrogance. Interestingly, both articles use the same photograph, suggesting it has been selected from an archive to represent her in this way by both publications.

So what does all this tell us about the attitudes of these articles towards divorce itself? Overall, there is an underlying approval of divorce when the marriage itself is judged to have been a mistake from the start. In this case, by reducing it to the simple, melodramatic form of the soap opera with its fixed and simplified character types, the conclusion is that the older good father (and talented musician) should divorce his greedy and demanding young wife, so that he can find someone more suitable. There is general approval in all three magazines when McCartney shows a readiness to 'move on' (for example the $W D$ October 9 article's headline 'Paul tells: I'M READY TO LIVE AGAIN' (p. 93)). The $N Z W W$ August 28 article even suggests a replacement romance for McCartney, with a photograph highlighting the suggestion that 'Stella ... has been trying to fix her dad up with a woman closer to his own age-Blythe Tanner, Gwyneth Paltrow's 63-year-old mother'.

There is an undertone of pity for their toddler, Beatrice - although that doesn't stop the magazines from publishing her photograph - and accompanying beliefs about divorcing parents' duty to put the needs of the child first. Again, the $N Z W W$ shows more discretion, including reference to her in only two articles out of the nine, compared with four out of 11 articles in the Woman's Day. New Idea's willingness to include publicity about her is the most pronounced, with six out of the nine articles discussing her welfare, often at length, and expressing very clear attitudes about the necessity of the couple putting aside their differences when it comes to the child, for example its first article has the headline 'Who's holding THE BABY?' (3 June, p. 12) and the September 16 article reports approvingly on a meeting the couple held to discuss her welfare.

There is also an array of positive and negative attitudes concerning the process of separation and what should and should not be done-what is acceptable and what is not. Prominent among them is the protagonists' behaviour around the financial settlement. Mills is depicted in the New Idea 
(14 October, p. 25) as 'plotting ... with her lawyers to fight tooth and nail for a large chunk of Sir Paul's fortune'. The use of the perjorative 'plotting' is typical of the highly coloured vocabulary used in discussion of this issue, and the tone of disdain for greed contrasts with repeated and lengthy speculations about the size of the settlement. These vary wildly, from \$NZ25 million to \$NZ 330 million. The conversion of British pounds to New Zealand dollars serves here to emphasise to New Zealand readers the large sums involved, and to reinforce the condemnation of Mills as a 'gold-digger'. The last article in the Woman's Day compares Mills unfavourably with the New Zealand model Rachel Hunter, who says she 'walked away with 'almost nothing' from her divorce from rocker Rod Stewart' (11 December, p. 13).

A divorcing couple are seen as in need of social support, for example the first $N Z W W$ article notes approvingly that McCartney 'has a very close-knit family and a good circle of friends'. The 'insiders' who are the chief informants in these articles are assumed to come from these groups, and their reports are accepted as partisan. While reporting and commenting on events, they also describe the feelings of Mills and McCartney. In one randomly selected article (New Idea, September 16, pp. 18-19), the couple and their child are variously described as worried, confused, distressed and humiliated. In this way socially appropriate emotional reactions to divorce are highlighted by the narrative.

Maintaining civility in public is also a minor theme which runs through some articles in each magazine. Mills arriving to find that McCartney had changed the locks on their house is the one incident where the authors appear to have sympathy with Mills' public humiliation, perhaps because there was photographic evidence. This contrasts with their reporting of her allegations of his bullying during the marriage, which are either explicitly or implicitly disbelieved. For example the Woman's Day article on October 30, which is devoted to this topic, spends the first column and a half on details of Mills' accusations, but devotes the remaining two columns to vehement refutations by a named spokesperson for McCartney. He is quoted as saying 'Heather Mills is a complete fantasist ... I know that the $\mathrm{b}^{* * * *}$ is up to ... she is trying to destroy Paul. She is trying to do the one thing which I have warned him about from the start' (p. 13). So bullying is of course wrong, but false accusations of bullying are represented as outrageous. In contrast, reports about the couple attending functions with their daughter together are uniformly 
approving in tone (for example the Woman's Day article on 13 November, with its headline 'Let it Bea: Paul and Heather bridge the gap' which reports on their joint attendance at her playcentre birthday party).

In short, these make up a view of divorce in which appearances of civility should be maintained, families and friends should be supportive, conflict over money is greedy and mean-spirited, self-seeking behaviour is not to be condoned, and a quick, cooperative settlement with generosity on both sides is better than a prolonged 'battle', with the aim that the couple should 'move on' with their separate lives as soon as possible. At no point in any of the magazines is there a suggestion that the couple should persevere with the marriage, not even for the sake of their child.

Also of interest is an attitude towards celebrity itself. The magazines' readers may be taking some comfort from the fact that even rich, clever and famous people suffer the strife and indignity of failure in their most intimate relationships. It is perhaps this appeal to Schadenfreude which tabloid magazines and newspapers are ultimately exploiting. For example, the NZWW article on November 6:

- uses 'we' ambiguously (it could mean 'we journalists' or 'we the public'): 'We've already heard ... but now we don't believe it', reinforcing the sense of the author and the reader sharing scathing commentaries about the protagonists in a way that makes the reader complicit

- addresses the reader directly: 'For those of you who do not have time to scour the internet for the latest developments ...', again promoting a sense of identification between the author and the reader, and flatteringly positioning the reader as someone who has more important things to do, but wants to get pleasure from hearing the worst about the subjects of the gossip

- $\quad$ and uses a jeering tone at the couple's expense: 'He begs her, 'Please, get help now' which, squashing two Beatles song titles into just four words, must be a record', again implicating the reader in the covert attack.

This positions the reader as someone who is old enough not to need the Beatles references explained, is interested in gossip as a form of entertainment, is not too concerned about the accuracy of the claims being made and who takes pleasure in the celebrities' misfortunes and mistakes. 
So people in the public eye such as Paul McCartney and Heather Mills are fair game for mocking references and judgements made of their private lives. This is in contrast to non-celebrities, whom magazines mostly represent in a positive light, for example as the brave survivors of accidents or illness (Bonner \& McKay, 2000). Envy is believed to be a key element in Schadenfreude (Van dijk, Ouwerkerk, Goslinga, Nieweg \& Gallucci, 2006), and it is tempting to conclude from a study of these particular examples of celebrity gossip that the rich and famous are singled out for this sometimes malicious treatment in print because they are so successful in the terms of Western society - their wealth and their fame - and 'we' (the public), in comparison are not.

An additional element comes into the attack on Heather Mills in particular: she is mocked for having previously courted media attention, and is mentioned in relation to Princess Diana in no fewer than five out of the eleven $N Z W W$ articles-mostly in terms of an unfavourable comparison. For example, the December 11 article discussed above contains an inset highlighted in pink with the quote: 'She craves attention and she always wanted to be the new Princess Diana'. The young wife is depicted as not only after the older man's wealth, but also his fame which, in a celebrity-ridden culture, can be seen as another form of equity. And it seems Mills is not playing the game. Tabloid journalists are supposed to hunt the unwilling celebrities, to flatter them when they are agreeable to being photographed, but then when they are not present, to criticise them for courting publicity. That Heather Mills was at first willing to be made famous in this way, and later resisted the vitriol their stories stirred up against her, perhaps says more about the gossip magazine phenomenon than it does about her.

\section{Conclusion}

The reading position that the authors of these texts put us in when we consume their texts is that of the covert observer of the private lives of people, like Heather Mills and Paul McCartney, who do not know us, but whose characters we believe we understand. We call them by their first names, and think we know their motivations and details of their most personal relationships. They are, however, presented to us in caricatures, as stock characters, not unlike some of those in the fairy stories of the Brothers Grimm or in melodramas and soap operas, and the relationship of 
the author to the reader is that of fellows privately discussing and judging the behaviour of people not present. The simplification (and commodification) this involves puts us in the position of consuming on-going narratives which are loosely based on real life, but which appeal to something much older than tabloids. If it is true that the act of gossiping has always been one of the ways we learn to conform to what we perceive to be generally accepted norms of behaviour, and to criticise others for not conforming to them, then the norms about divorce that are proposed in these articles may represent commonly held views in New Zealand society. And if gossip magazines can tell us anything about the attitudes towards divorce of their readers it is that, in circumstances where a beautiful but greedy younger woman has fooled a rich older man into thinking she is in love with him, divorce is not only an acceptable outcome, it is the best outcome. At the time of writing this article, the case is again in the gossip magazines, even in the so-called 'hard news' publications such as The Times (TimesOnline, 11 April 2008). We await the next episode with interest.

Articles included in the discussion (all from 2006)

New Idea (NZ edition), 3 June (p. 2); 17 June (p. 9); 23 July (p. 6); 16 September (pp. 18-19); 14 October (pp. 24-25); 28 October (pp. 14-15); 4 November (pp. 6-17); 11 November (pp. 12-13); 25 November (p. 21); 2 December (p. 9); 30 December (p. 19).

New Zealand Woman's Weekly, 3 July (pp. 6-17); 17 July (p. 6); 14 August (p. 4); 28 August (pp. 12-13); 9 October (p. 4); 6 November (p. 14); 13 November (pp. 14-15); 11 December (p. 4); 18 December (pp. 14-15).

Woman's Day (NZ edition), 5 June (p. 14); 19 June (p. 109); 26 June (pp. 14-15); 10 July (pp. 14-15); 14 August (pp. 16-17); 21 August (pp. 14-15); 28 August (p. 20); 25 September (pp. 18-19); 9 October (p. 93); 30 October (pp. 12-13); 6 November (p. 20); 13 November (p. 102); 4 December (p. 23); 11 December (p. 13).

\section{References}

ABC Knowledge Base. Retrieved on 24 April 2009, from http://magazine.abc.org. nz/audit.html.

Ang, I. (1996). Living room wars: Rethinking media audiences for a postmodern world. London: Routledge.

Baumeister, R., Zhang, L. and Vohs, K. (2004). Gossip as cultural learning. Review of General Psychology 8(2): 111-121.

Bonner, F. and McKay, S. (2000). Challenges, determination and triumphs: inspirational discourse in women's magazine health stories. Continuum: Journal of Media and Cultural Studies 14(2): 133-144. 
Brown, G. and Yule, G. (1998). The role of context in interpretations. In G. Brown and G. Yule. (Eds.) Discourse Analysis (pp. 27-67). Cambridge: Cambridge University Press.

Chouliaraki, L. and N. Fairclough (2001). Discourse in late modernity: rethinking critical discourse analysis. Edinburgh: Edinburgh University Press.

Dijk, W., Ouwerkerk, J., Goslinga, S., Nieweg, M. and Gallucci, M. (2006). When people fall from grace: reconsidering the role of envy in Schadenfreude. Emotion 6(1): 156-160.

Fisher, W. (1987). Technical logic, rhetorical logic, and narrative rationality. Argumentation 1: 3-21.

Foster, E. (2004). Research on gossip: taxonomy, methods and future directions. Review of General Psychology 8(2): 78-99.

Fulton, H., Huisman, R., Murphet, J. and Dunn, A. (2005). Narrative and media. Melbourne: Cambridge University Press.

Gledhill, C., Ed. (1987). Home is where the heart is: Studies in melodrama and the woman's film. London: British Film Institute.

Heather Mills launches new attack on Sir Paul McCartney - and lawyer. (2008, Apri1 11). The Times. Retrieved on 12 June 2008, from www.timesonline.co.uk/ tol/news/uk/article3727748.ece.

Hillcoat-Nalletamby, S., Dharmalingam, A. and Baxendine, S. (2006). Living together or communicating at a distance: structural and associational solidarity between mid-life parent and adult child in New Zealand. Journal of Comparative Family Studies 37(3): 381-399.

Kress, G. and Van Leeuwen, T. (1999). Representation and interaction: designing the position of the viewer. In A. Jaworski and N. Coupland. The Discourse reader (pp. 377-404). London: Routledge.

Lacey, N. (2000). Narrative and genre: key concepts in media studies. London: Macmillan.

Mcandrew, F., Bell, E. and Garcia, C. (2007). 'Who do we tell and whom do we tell on?' Gossip as a strategy for social enhancement. Journal of Applied Social Psychology 37(7): 1562-1577.

Mcandrew, F. and Milenkovic, M. (2002). Of tabloids and family secrets: the evolutionary psychology of gossip. Journal of Applied Social Psychology 32(5): 1064-1082.

McKay, S. and Bonner, F. (2000). Introduction. Continuum: Journal of Media and Cultural Studies 14(2).

McCartney eclipses rivals' wealth. (March 2004). Retrieved on 15 May 2008, from http://news.bbc.co.uk/1/hi/entertainment/music/3537241.stm

Scharrer, E., Weidman L., and Bissell, K. (2003). Pointing the finger of blame: news media coverage of popular-culture culpability. Journalism and Communication Monographs 5(2): 47-98.

Thornton, A. and Young-DeMarco, L. (2001). Four decades of trends in attitudes toward family issues in the United States: the 1960s through the 1990s. Journal of Marriage and Family 63(4): 1009-1038. 
Weimann, G. (2000). Communicating unreality: modern media and the reconstruction of reality. London: Sage.

Wert, S. R. and Salovey, P. (2004). A social comparison of gossip. Review of General Psychology 8(2): 122-137.

Rosemary Brewer is a senior lecturer and programme leader in communication studies at AUT University. Her research interests include persuasive communication, women's magazines and on-line learning networks. rosemary.brewer@aut.ac.nz

\section{\$1000 PRIZE FOR EXCELLENCE}

THE GEORGE MUNSTER AWARD FOR

INDEPENDENT JOURNALISM

\section{Australian Centre for Independent Journalism} University of Technology, Sydney

Open to journalists for an outstanding piece of work published or broadcast in any medium in Australia which shows independence of mind, acuity and excellence in terms of craft. Applicants must have been ordinarily resident in Australia for no less than twelve months prior to 30 June 2009.

Entries for the 2009 Award close on Friday, 17 July 2009.

The presentation will be made on Friday, 11 September 2009 at the George Munster Journalism Forum, UTS.

For more information, contact Jan McClelland, Manager, ACIJ, PO Box 123, Broadway 2007 Australia

Tel: + 61295142295 Fax: +61295141890

Email: acij@uts.edu.au

Applications available at www.acij.uts.edu.au/awards 